\title{
Security Analysis, Agency Costs, and UK Firm Characteristics
}

\author{
John A. Doukas, Phillip J. McKnight, and Christos Pantzalis*
}

January 14, 2002

\begin{abstract}
The purpose of this paper is to assess the monitoring power of security analysts from the manager-shareholder conflict perspective. Using a net sample of 1,027 UK firms tracked by security analysts over the 1998-2000 period, our evidence supports the view that security analysis acts as a monitoring mechanism in reducing agency costs. More importantly, we also find that security analysts are more effective in reducing managerial non-value maximising behaviour for smaller and more focused firms rather than larger and more diversified firms supporting the supposition that as firms grow larger and more complex, the monitoring activity of security analysis becomes less effective with firm size. In addition, the evidence points out that security analysis has a positive and significant impact on firm value for smaller firms as opposed to larger ones. Overall, the UK findings suggest that the monitoring role of security analysts is not restricted to the U.S. capital market environment.
\end{abstract}

Key words: Security Analysis; Analyst Coverage; Agency Costs; Firm Value.

JEL classifications: G24, G34

*Department of Finance, Stern School of Business, NYU, School of Business and Public Administration, Old Dominion University, Norfolk, VA 23529-0218, Tel:(757) 683-5521, Fax:(757) 683-5639, E-mail: jdoukas@stern.nyu.edu; Distinguished Professor of Finance Cardiff University; Department of Accounting and Finance, Cardiff Business School, Cardiff, UK CF10 3EU, Tel: 02920 876804, Fax: 02920876804 E-mail mcknightpj@cardiff.ac.uk; Department of Finance, College of Business Administration, University of South Florida, Tampa, FL 33620-5500, Tel:(813) 974-6326, Fax:(813) 974-3030, E-mail: cpantzal@coba.usf.edu, respectively.

We are grateful for the financial support provided by The Leverhulme Trust. We would also like to acknowledge Multx Global Estimates for providing most of the data comprising this paper possible. 


\title{
Security Analysis, Agency Costs, and UK Firm Characteristics
}

\begin{abstract}
The purpose of this paper is to assess the monitoring power of security analysts from the manager-shareholder conflict perspective. Using a net sample of 1,027 UK firms tracked by security analysts over the 1998-2000 period, our evidence supports the view that security analysis acts as a monitoring mechanism in reducing agency costs. More importantly, we also find that security analysts are more effective in reducing managerial non-value maximising behaviour for smaller and more focused firms rather than larger and more diversified firms supporting the supposition that as firms grow larger and more complex, the monitoring activity of security analysis becomes less effective with firm size. In addition, the evidence points out that security analysis has a positive and significant impact on firm value for smaller firms as opposed to larger ones. Overall, the UK findings suggest that the monitoring role of security analysts is not restricted to the U.S. capital market environment.
\end{abstract}

Key words: Security Analysis; Analyst Coverage; Agency Costs; Firm Value.

JEL classifications: G24, G34

We are grateful for the financial support provided by The Leverhulme Trust. We would also like to acknowledge Multx Global Estimates for providing most of the data comprising this paper possible. 


\section{Introduction}

The basic role of information intermediaries, such as security analysts, is to collect, process and disseminate information to interested users. Analysts normally conduct firm- and industry-specific research whose findings are conveyed to the public in the form of annual reports and earnings per share announcements that are predictive in nature. ${ }^{1}$ Brokerage firms employ thousands of security analysts and make enormous investments in gathering, analysing, and using such information in their stock recommendations (Womack (1996)).

Stock prices tend to respond more to changes in analysts' forecasts of earnings than they do to changes in earnings themselves, indicating the usefulness of analysts' earnings forecasts (Elton, Gruber, and Gultekin (1981)). La Porta (1996) argues that security analysts' forecasts represent a relatively good proxy market's earnings expectations of future earnings. Security analyst reports have increasingly become of considerable interest to both individual and institutional investors (Cragg and Malkiel (1968), Malkiel (1982), Givoly and Lakonishok (1984), La Porta (1996) Chung and Jo (1996)). As Figure 1 indicates, the demand for analyst services in the UK has seen a sharp increase over the past three years. From the 1,295 UK quoted companies listed over the London Stock Exchange, the number of UK firms covered by security analysts in June 1998 was 689 while by June 2001 analyst coverage nearly doubled to 1,185 firms. To the extent that the number of analysts represents investor demand for the services provided by security analysis (Bhushan (1989)), this suggests that investors have increasingly become aware of the importance of analyst services.

One economic benefit of security analysis is that it increases the transparency of the firm by extracting and disseminating firm-specific information to existing and potential investors. In 
that capacity, security analysis assists investors in their investment decision making process. More importantly, it is argued that security analysis may be a crucial monitoring mechanism, analogous to that of bond rating agencies or the non-executive directors of a firm's board (Fama, 1980; Fama and Jensen, 1985). Jensen and Meckling (1976), in their seminal article, conjectured that security analysis should not only exert a positive influence on firm value, but should also decrease agency costs by limiting managerial non-value maximising activities.

\section{[Insert Figure 1 About Here]}

The debate on the value of security analysis has been revived by Womack (1996), who finds that stock prices are influenced by analysts' forecasts and Doukas et al (2000), who show that the monitoring role of security analysts reduces managerial misconduct. To our knowledge, the importance of security analysis and its impact on UK firms has not received the required attention of academic research. This is surprising given that analyst coverage has dramatically increased over the recent past. Despite the enormous growth of the information intermediaries industry, little is known about the influence analyst coverage may have on firm value and the salient agency cost problem between managers and outside shareholders in the UK setting. Previous research has exclusively focused on U.S. firms (Womack (1996), Chung and Ho, 1996; Doukas, Kim, and Pentzalis, 2000). While the findings of these studies are consistent with the prediction of Jensen and Meckling (1977) that security analysis increases firm value by restricting managerial misconduct, it cannot be ruled out that this is simply the outcome of an elaborate data snooping process. Without testing the robustness of these findings outside the U.S. environment in which they were found, we cannot determine whether these empirical regularities are merely spurious or dependant on the institutional setting of the U.S. financial markets. In this paper, we

1 Francis and Philbrick (1993) suggest that accountants put forth much effort on analysing the earnings estimates 
ask whether UK security analysis, as predicted by Jensen and Meckling (1976), exerts a (1) positive influence on firm value, and (2) negative impact on agency costs. The exact nature and extent to which security analysis affects firm value and managerial conduct in UK firms remains the central focus of this investigation.

An added feature of this investigation is that we examine the importance of analyst coverage with regard to size of the firm. It is generally believed that larger firms fail to increase shareholder value because of over investment and agency costs (Jensen, 1986; Stulz, 1990; Denis, Denis and Sarin, 1997; Doukas, Kim and Pantzalis, 2000) as well as because of internal capital market inefficiencies (Lamont, 1997; Shin and Stulz, 1998; Rajan, Servaes and Zingales, 2000). Bhushan (1989) asserts that, greater cost and the complexity of gathering and analysing data for larger firms, the monitoring activity of security analysis is predicted to be less effective for larger than smaller. Aware of burdens to analyst in acquiring and evaluating information from large and complex corporate organizations, many managers cite the desire to mitigate this problem by issuing tracking stock. The tracking stock innovation itself and the related empirical evidence raise also the question of whether the monitoring activity of security analysis is uniform across firms with size differences. ${ }^{2}$ In this paper, we also examine whether the effectiveness of security analysts, as a monitoring mechanism in reducing agency costs associated with the managershareholder conflict, is mitigated by firm size due to greater informational asymmetries believed to exist in larger than smaller firms.

This paper is organised as follows. Section 2 describes the monitoring role of security analysts in the context of the manager-shareholder conflict. Section 3 describes the sample

and cash flow forecasts of analysts.

2 Gilson, Healy, Noe and Palepu (1998) find that analyst coverage and the quality of such coverage, measured by analyst forecast errors, increase following the issuance of tracking stock. 
selection, model specification, and variable measurement. Section 4 presents and discusses the results. Section 6 provides a summary and conclusions.

\section{The Monitoring Role of Security Analysts}

Agency costs arise from the improper alignment of interests of the firm's managers with those of the firm's shareholders. Jensen and Meckling (1976) also argue that shareholders incur agency costs when management owns less than 100 percent of the firm's equity. Consistent with Jensen and Meckling (1976), Nohel and Tarhan (1998) point out that the agency problem (conflict) is caused by the physical presence of excess cash and certain investments that are considered liquid. The shareholders primary concern is that the presence of such excess cash may create an environment where management makes witless decisions that deplete this precious resource; that is, decisions that are detrimental to the firm such as the funding of negative net present value (NPV) projects and through perquisite consumption. Agency costs may take on many forms, most notably job perks, shirking, and the making of decisions by management aimed at enhancing their own interests as opposed to that of the shareholders. The magnitude of these costs can be unlimited unless the actions of managers are properly scrutinized by monitoring mechanisms such as banks, investment houses, and, most importantly, security analysts. ${ }^{3}$ Agency costs may also be independent of certain issues relating to ownership and control structure of the firm (Ang, Cole, and Lin; 2000). For example, where, on the one hand, agency costs may be an inverse function of the managers' ownership stake, it may also be perceived as an increasing function of the number of non-manager shareholders.

3 We believe that security analysis provides not so much a direct but rather an indirect monitoring function given their main role is to gather and analyse information as opposed to carrying out, for example, an auditing responsibility. 
Jensen and Meckling (1976), argue that the monitoring activity of security analysis helps to reduce agency costs associated with the separation of ownership and control by restricting the non-value-maximising behaviour of managers. This implies, then, that agency costs should decline as a result of the monitoring activity of security analysts. Prior research has examined the determinants (Bhushan, 1989; Moyer, Chartfield, and Sisneros, 1989; and Brennan and Hughes, 1991) and the valuation effects (Chung and Jo, 1996) of security analysis. While these studies provide interesting insights about security analysts, they do not directly examine the effects of security analysis on the agency conflict between managers and shareholders. Perhaps the only study to examine this issue directly is by Doukas et al (2000) based on the U.S. The evidence of this study shows that security analysts act as a monitoring mechanism in reducing agency costs for smaller and focused than larger and diversified firms. This study also found that firm value is positively related to security analyst coverage. That is, security analysis seems to exert greater influence on the value of smaller rather than larger firms.

The extent to which security analysis serves as an external monitoring device in terms of reducing agency costs (i.e., restricting managers' non-value-maximising behaviour) in other capital market environments such as the UK firms remains an empirical question. ${ }^{4}$ With the demand for analyst services on the rise, one could surmise that analyst following will assume a similar monitoring role for UK firms as found in US firms. Moreover, since non-value-maximising conduct by managers is more likely to occur in larger (often multi-divisional) rather than smaller

\footnotetext{
4 Analogous to other internal and external monitoring mechanisms, such as independent boards of directors, bond-ratings, investment banks and takeovers.
} 
(often focused) firms, we also investigate whether the monitoring effectiveness of security analysis is related to firm size. ${ }^{5}$

We hypothesise that the monitoring effectiveness of security analysts is lower for smaller more focused firms rather than larger more diversified firms because larger firms are more complex organisations to be assessed and monitored by analysts. This conjecture also suggests that larger firms are subject to greater information asymmetries than smaller firms. As a result, they are less transparent and more likely to be subject to greater agency costs than smaller firms. Consequently, analysing security analysts' monitoring of managerial activity puts the managershareholder conflict to a new test, whereas it allows us to examine the relative monitoring efficiency of security analysts across firms with differences in size. Finally, if security analysis mitigates managerial misconduct it is expected that its valuation effects should also vary across firms of different size. In this study, we also address whether the valuation effects of security are larger for smaller than larger firms. ${ }^{6}$

In sum, the objectives of this paper are twofold. First, we examine directly whether security analysis acts as a monitoring mechanism in restricting agency-related costs arising from the separation of ownership and control in UK publicly traded firms. Second, we investigate whether the effectiveness of the monitoring activity of security analysis is related to firm size.

\footnotetext{
5 Agency costs associated with over-investment activity may also arise from managerial compensation that is tied to firm size (Jensen and Murphy (1990)), or from the managers' desire to become indispensable to the firm (Shleifer and Vishny (1989)), to increase their power and prestige (Jensen (1986), Stulz (1990)), or to reduce the risk of their personal wealth portfolios (Amihud and Lev (1981)).

${ }^{6}$ Increased public awareness of the firm due to firm's coverage by analysts can also result in increased volume of trading and in higher market valuation (Merton (1987), and Brennan and Hughes (1991)).
} 


\section{Sample Selection, Methodology, and Variable Measurement}

\subsection{Sample Selection}

Our data spans the period 1998 to 2000 inclusive. A key variable in the study is the number of analysts following the firm (NAF - the number of analysts following each firm which provide earnings-per-share estimates) and this information is provided by Multex Global Estimates. We use analyst coverage data available each year for the one year and two years-ahead forecasting horizons. ${ }^{7}$ Our measures of agency costs needed certain data inputs for calculating: (i) Tobin's q; (ii) operating income; and (iii) growth in sales. Firms in our sample are required to have financial data available on a set of control variables, such as director shareholdings, institutional shareholdings, size, and industrial segment. This information is obtained from the DataStream, Hemscott's Company Guide, and FAME (Financial Analysis Made Easy). Given the unavailability of some data with regard to the above criteria, the net sample consists of 1,027 firms.

Table 1 provides descriptive statistics for both financial and ownership structure characteristics of the firms in the sample. Moreover, means [medians] and standard deviations for the smaller $\left(30^{\text {th }}\right.$ percentile $)$ and larger $\left(30^{\text {th }}\right.$ percentile $)$ firms are also reported in Table 1 . The last column lists the $t$ [Wilcoxon rank sum $z$ ] - statistics for the mean [median] difference tests between the smaller $30^{\text {th }}$ percentile and the larger $30^{\text {th }}$ percentile of firms. On average, larger firms have significantly lower Tobin's q values $(Q)$ and sales growth rates $(G S)$. Smaller firms have lower Long-Term debt ratios (LTD), and Total Annual Sales (SIZE). The mean difference tests indicate that there are significant differences in terms of ownership structure characteristics across

\footnotetext{
7 See also Chung and Jo (1996).
} 
small- and large-cap firms. Smaller firms exhibit, on average, higher insider ownership (INSIDE) and slightly lower institutional ownership (INSTIT) in comparison to larger firms. As expected, smaller firms are significantly less diversified (fewer business segments) than larger firms, suggesting that large/diversified firms are probably less transparent and more difficult for security analysts to monitor their activities.

The means [medians] difference tests between smaller and larger firms reveal that the number of analysts following $(N A F)$ larger firms is on average significantly higher compared to analysts following smaller firms. If the number of analysts is a proxy for the total expenditures on information acquisition about a firm (Bhushan, 1989), this result suggests in general that more resources are spent for acquisition of private information for larger than smaller firms. ${ }^{8}$ This also implies that the demand for forecast services may be greater for larger than smaller firms. Our evidence suggests that the higher cost of information acquisition associated with larger firms is outweighed by the strong demand for information generated by analysts for such firms. Therefore, the fact that more information is produced by security analysts for larger and, in many instances, that diversified firms coupled with the documented evidence that they are trading at a discount in comparison to smaller firms, raises concerns about the monitoring role of security analysis as well.

[Insert Table 1 About Here]

\subsection{Model Specification}

\footnotetext{
8 In this paper we do not deal explicitly with issues of "free riding" , "resale of analyst services", and "salary differences among analysts".
} 
Jensen and Meckling's (1976) argument about the monitoring role of security analysis suggests that firms that are followed by more security analysts should be subject to lower agency costs. The monitoring role of security analysis predicts a negative relation between agency costs and analyst coverage. The relation between agency costs and analyst coverage is examined by using alternative measures of agency costs. Because our agency cost measures are censored at zero, a regression procedure becomes appropriate. We therefore estimate the following regression equation in testing the relationship between agency cost and analyst coverage. $A G E N C Y=\alpha_{0}+\alpha_{1} N A F+\alpha_{2} N A F \mathbf{x} D U M-S+\alpha_{3} N A F x D U M-L+\alpha_{4} I N S I D E+\alpha_{5} I N S I D E^{2}+\alpha_{6} I N S T I T+$
$\alpha_{7} L T D+\alpha_{8} L T D^{2}+\alpha_{9} S I Z E$

Since the above equation examines the monitoring effects of security analysis on agency costs, it tells us very little about the direct effects of security analysts on firm value. Thus, we employ the following model for testing the impact analyst following $(N A F)$ has on firm value $(F V)$.

$F V=\alpha_{0}+\alpha_{1} N A F+\alpha_{2} N A F \mathbf{x} D U M-S+\alpha_{3} N A F x D U M-L+\alpha_{4} I N S I D E+\alpha_{5} I N S I D E^{2}+\alpha_{6} I N S T I T+\alpha_{7} L T D+$ $\alpha_{8} L T D^{2}+\alpha_{9} S I Z E$

\subsection{Variable measurement}

We use three alternative measures of agency costs $(A G E N C Y)$ derived from variables that frequently appear in the accounting and finance literature, with AGENCY denoting the interaction of the firm's growth opportunities and its free cash flows. We measure the growth opportunities of the firm using three indicator variables. The first indicator variable takes the value of one if the firm's Tobin's q (Q-based) is less than the sample median (i.e., poorly managed firm) and the value of zero otherwise. The second agency cost measure takes the value of one if the firm's five- 
year growth of sales (GS) is less than the sample median and the value of zero otherwise. Finally, a third agency cost measure, operating expense (OE) standardised by total annual sales, takes the value of one if the $\mathrm{OE}$ ratio is greater than the sample median and the value of zero otherwise.

Following Lehn and Poulsen (1989), free cash flows (FCF) are measured as Operating Income before Depreciation minus the sum of Taxes plus Interest Expense and Dividends paid, standardised by Total Assets. Therefore, given the level of corporate free cash flows, firms with low (high) growth opportunities are expected to be subject to high (low) agency costs. Poorly managed firms are more likely to be exposed to higher agency costs than well managed firms and consequently waste free cash flows in negative NPV projects while well managed firms are expected to be involved in value maximising activities where free cash flows are not expected to be wasted. Specifically, a high value for the interactive $A G E N C Y$ variable would be indicative of a firm with high agency costs arising from the existence of high free cash flows at the discretion of its managers and being poorly managed. In summary, our Q-based $A G E N C Y$ variable is defined as $Q-D U M M Y \times F C F$, median growth in sales-based $A G E N C Y$ variable is $G S-D U M M Y \times F C F$, and median of operating expense-based $A G E N C Y$ variable is $O E-D U M M Y \times F C F$.

$N A F$ is the number of analysts following a firm that provide earnings-per-share forecasts for each firm in the sample. We also use the log of one plus the number of analyst $(1+N A F)$ following the firm, rather than using the raw number of analysts. Following Hong, Lim, and Stein (2000), we do so because one extra analyst should matter much more in this regard if a firm has few analysts than if it has many. Consistent with the monitoring hypothesis of security analysis, a negative relationship is predicted between agency costs and the number of security analysts following a firm. In addition, if security analysis is less effective in limiting managerial non-valuemaximising behaviour for larger than smaller firms, it is predicted that the coefficient of the 
security analysis variable $(N A F)$ should be statistically insignificant. We, therefore, introduce two interaction terms between security analysts and two firm-size indicator variables, for the smallest $(D U M-S)$ and largest (DUM-L) $30^{\text {th }}$ percentile of firms, NAFxDUM-S and NAFxDUM-L, respectively. The coefficient of the interactive term provides a direct estimate of the differential impact security analysis has on the agency cost measures between smaller and larger firms. In short, our objective here is to determine whether the monitoring effects of security analysis differ between smaller and larger firms. The regression analysis is repeated across all forecasting horizons.

To reduce the possibility of model misspecification, a set of control variables that characterise the firm's ownership structure, leverage, and size are also used in the analysis. Bhushan (1989), Moyer, Chatfield, and Sisneros (1989), and Brennan and Hughes (1991) find that analyst following is positively associated with these variables, and are thus considered as the more common control variables. ${ }^{9}$ The INSIDE variable used in the analysis measures the percent of common shares held by insiders (i.e., managers and members of the board of directors). The greater the ownership dispersion of the firm the greater the non-value-maximising behaviour of managers, and therefore, the greater the agency costs. The use of INSIDE is intended to capture the aligned interests between insiders and shareholders. Therefore, it is expected that the larger the ownership stakes by insiders the lower the agency costs. The squared term, INSIDE ${ }^{2}$, is also used to account for possible non-linear insider ownership effects on agency costs (i.e., non-value maximizing behaviour by entrenched managers). Furthermore, agency conflicts between managers and shareholders are likely to be mitigated through the monitoring activities of institutional

\footnotetext{
${ }^{9}$ R\& D intensive firms are also more likely to be followed by more analyst (Chung and Jo, 1996) primarily because these firms are generally of higher quality and recognised as industry leaders. Unfortunately, R\&D data was
} 
investors. The INSTIT measure, then, is used as the percent of shares held by institutional investors. Institutional ownership would point out the extent of outside monitoring of managerial behaviour. However, institutional shareholders may be ineffective monitors because they have little time or resources to devote to active monitoring beyond that of under-performing firms in which they have large equity stakes (Berle (1959), Pound (1988)). LTD is the book value of Long-Term Debt divided by the book value of the Total Assets. This variable is used to control for the monitoring role of debt on managers' discretion over free cash flows. It is anticipated that the agency cost measures should be inversely related to the fraction of debt in the firm's capital structure. However, monitoring provided by debt holders may not be effective until the debt level reaches a critical threshold. This is examined with the inclusion of the squared $L T D$ variable in the analysis. SIZE is the firm's Total Annual Sales. Since agency conflicts are more pronounced in larger organisations, a positive relation between size and agency costs is expected. Finally, SEG represents the number of segments as identified by the 2-digit SIC code for each firm in the sample.

\section{Empirical Evidence}

\subsection{Agency Costs}

Table 2 presents empirical evidence for the relation between agency costs, AGENCY, and analysts coverage, $N A F$, across all forecasting horizons. The coefficients found in Panel A for the $N A F$ variable are 0.006 ( $t$-value of .816) and 0.003 ( $t$-value of .906) for the one-year and twoyear forecasting horizons, respectively. The coefficients were, however, insignificant suggesting that $N A F$ exerts little influence on reducing agency costs in all firms. On the other hand, once the firms are segregated by size, the coefficient of the interactive variable NAF $x$ DUM-S becomes 
negative and statistically significant for all agency cost variables, suggesting that the monitoring role of security analysis is much more pronounced for smaller and more focused firms rather than larger and more diversified firms. As evidenced in Panel A (Q-based agency cost measure) of Table 2, the coefficients of the NAF $x$ DUM-S interactive variable are -0.016 ( $t$-value of -3.260 ) and -0.012 ( $t$-value of -2.328$)$ for the one-year and two-year forecasting horizons, respectively. Moreover, the relation between agency costs and analyst coverage, as shown in Panel B (median growth of sales-based agency cost measure) and Panel C (median growth of operating expensebased agency cost measure), appears to be insensitive to the measure of agency cost used.

As hypothesised, these results imply that the number of analyst following the firm exerts substantially greater influence on reducing agency costs for smaller and more focused firms rather than larger and more diversified firms. One plausible agency-based explanation is that monitoring of larger firms is met with much difficulty given the size and complexity of these firms and their accompanying information asymmetries. Alternatively, our evidence implies that the monitoring activity of security analysis has failed to reduce internal capital market inefficiencies and overinvestment activity in larger firms.

The coefficients for our control variables are also presented in Table 2. The coefficient of the INSIDE variable was significant and negative for both $N A F$ forecasting horizons in Panel C (and insignificant for all forecasting horizons in Panel B). This finding supports Jensen and Meckling's (1976) convergence of interest argument, at low levels of managerial ownership, that states that managers are not inclined to divert resources away from value maximisation. Moreover, although not significant, the negative INSIDE squared variable indicates that inside ownership may have curve-linear effects on agency costs. These results support the view that high 
levels of inside ownership, driven by non-convergence of interests between inside and outside owners of the firm, and managerial equity ownership entrenchment motives, are associated with high agency costs. Equally as important is the INSTIT variable. Its coefficient is positive and significant in the regressions reported in Panel C, suggesting that institutional ownership may be associated with higher agency costs. This result supports the view that institutional ownership of the firm sides with managers rather than monitoring managerial misconduct probably because of special relations that may exist between institutions and the managers of the firm (Pound, 1988). The coefficients of $L T D$ term and squared term of $L T D$ are insignificant suggesting that debtholders play no substantive role in monitoring managerial conduct.

[Insert Table 2 About Here]

\subsection{Firm Value and Analyst Coverage}

Although the evidence suggests that the monitoring effects of security analysis are considerably larger for smaller firms as opposed to larger firms, very little is known about the extent to which analyst following impacts firm value. To find out the valuation effects of security analysis issue we examine the relation between firm value and the number of security analysts including a set of control variables to account for other effects. ${ }^{10}$ We use two measures of value: Tobin's q (Q) and Excess Market Value (EMV). Furthermore, in order to determine whether the valuation effects of security analysis vary with firm size, we introduce two indicator variables: $N A F x D U M-S$ representing the smallest 30 percent of the firms and NAFxDUM-L representing the largest 30 percent in the sample, a technique identical to that used in the agency cost analysis.

\footnotetext{
${ }^{10}$ Tobin's q is measured by [Market Value of Equity + Book Value Debt]/Total Assets in conjunction with McConnell and Servaes, 1990. The q values are estimated after the announcement of actual earnings forecasted by security analysts.
} 
Table 3 provides the empirical findings for both measures of firm value. The coefficient of the number of security analysts following variable, $N A F$, is positive and mostly statistically significant. As shown in Panel A, the coefficients of the $N A F$ variable are 0.308 (with t-value of 1.866) and 0.318 (with t-value of 1.996) for the one-year and two-year forecasting horizons, respectively. The results based on the EMV valuation measure are statistically significant in all forecasting horizons. The coefficients of the $N A F$ variable are 1.907 (with t-value of 5.457) and 1.594 (with t-value of 4.631) for the one-year and two-year forecasting horizons, respectively. Consistent with the conjecture of Jensen and Meckling (1976) and recent evidence (Chung and Jo (1996), and Doukas et al (2000)) these results suggest that analyst following has a positive and significant effect on firm value. Thus, the relation between value and analyst coverage is insensitive to the value measure used. Moreover, as shown in Panel A, the interactive variable $N A F \mathrm{x} D U M-S$ has a much stronger and positive coefficient, 0.625 (with t-value of 2.459) and 0.542 (with t-value of 2.113) for the one-year and two-year forecasting horizons, than that found for the $N A F$ variable. Interestingly, the coefficients for $N A F x D U M-L$ are insignificant for all forecasting horizons suggesting that security analysis has little influence on Q. Panel B, reports similar results indicating that this finding is also insensitive to the measure of firm value used. In agreement with the previous results, which show that security analysis has greater monitoring effect on smaller and more focused firms than larger and more diversified firms (i.e., managerial misconduct is more (less) discernible in smaller (larger) firms by security analysts), these findings indicate that security analysis has greater valuation effects on smaller than larger firms.

As for our control variables, the coefficient of the INSIDE variable is mostly positive and insignificant in all regressions of Panel A. As shown in Panel B, its coefficient turns negative and significant in all regressions suggesting that low levels of insider ownership are harmful to firm 
value. The statistically insignificant coefficient of the squared INSIDE variable, reported in Panel B, however, suggests that a non-linear relation exists between firm value and insider ownership. The sign of the coefficient of institutional ownership variable, INSTIT, is negative and statistically significant in all regressions regardless the measure of firm value and forecasting horizon used. This indicates that firm value is a decreasing function of institutional ownership consistent with the findings reported in Table 2 that show that institutional shareholders do not restrict agency costs associated with managerial misconduct. The coefficients of the LTD and the squared term of $L T D$ variables suggest that debt's monitoring role becomes binding above a critical threshold. The negative coefficient of the SIZE variable implies that firm value is adversely affected by size.

Our empirical results suggest that the valuation effect of analyst following is greater for smaller and more focused firms. We also find that the value of security analysis falls when firms become larger and more diversified, especially those in the largest $30^{\text {th }}$ percentile of firms in our sample. In short, the monitoring of larger firms by security analysts fails to add shareholder value mainly because of the difficulty to discipline managerial non-value-maximising behaviour in these firms. Analysts are at a considerable disadvantage in disentangling asymmetries of information associated with larger firms, i.e., costs constraints arising from information acquisition. Hence, it can be argued that the limitations of security analysis in monitoring managerial misconduct in larger and complex firms may be another reason why larger firms tend to trade at discounts with respect to smaller firms.

[Insert Table 3 About Here]

\section{Summary and Conclusions}

Jensen and Meckling's (1976) "agency theory" is perhaps one of the more important contributions to the modern finance literature. One of the views espoused by the authors is that 
security analysis activities should reduce agency costs associated with the separation of ownership and control. Job perks, shirking, and decisions taken at maximising the managers utility are just a few forms of agency costs and these costs can be boundless unless managerial actions are properly monitored.

The extent to which security analysis activities through its monitoring role reduces agency costs has not been tested directly in the $\mathrm{U} . \mathrm{K}$ and this is surprising given the growing importance placed on security analysts by the economic and financial communities to provide investment guidance. As a result of this shortcoming, we examine the monitoring role of security analysis. Second, we examine whether the ability of security analysis is related to the size of the firm. Finally, we investigate the valuation effects of security analysis across firms with different size characteristics. Our evidence is consistent with the view that security analysis has monitoring capabilities in reducing agency costs. We find empirical support for the notion that security analysis is considerably less effective in restricting managers' non-value maximising behaviour for larger and more diversified firms rather than smaller and more focused firms. Third, while our empirical results indicate that firm value is a positive function of security analysis, security analysis also seems to exert greater influence on the value of smaller rather than larger firms. In short, these findings suggest that the usefulness of security analysis seems to diminish with size/diversification of the firm despite the fact that more resources (i.e., more analysts (Bhushan (1989)) are spent for the acquisition and evaluation of private information for larger than smaller firms. Overall, in accord with the U.S. evidence on the monitoring role of security analysis (Doukas et al (2000)), our findings suggest that UK information intermediaries, such as security analysts, reduce agency costs associated with the separation of ownership and control as 
conjectured by Jensen and Meckling (1976). Our results suggest that the monitoring role of security analysts is not limited to the U.S. capital market environment.

\section{References}

Amihud, Y., and B. Lev, 1981, Risk reduction as a managerial motive for conglomerate mergers. The Bell Journal of Economics 12: 605-617.

Ang, J., R. Cole, and J, Lin, 2000, Agency costs and ownership structure. Journal of Finance 50: 81-106.

Berle, A., 1959, Power without property : A new development in American political economy, New York: Harcout Brace and World.

Berger, P., and E. Ofek, 1995, Diversification's effect on firm value. Journal of Financial Economics 37: 39-65.

Bhushan, R, 1989, Firm characteristics and analyst following, Journal of Accounting and Economics 37; 39-65

Billett, M., and S. Mauer,1998, Diversification and the value of internal capital markets: The case of tracking stock, Working paper (South Methodist University, Dallas,TX).

Brennan, M., and A. Subrahmanyam, 1995, Investment analysis and price formation in security markets. Journal of Financial Economics 38: 361-381.

Brennan, M., and P.Hughes, 1991, Stock prices and the supply of information. Journal of Finance 46: 1665-1691.

Chung, K. H., and H. Jo, 1996, The impact of security analysts' monitoring and marketing functions on the market value of firms. Journal of Financial and Quantitative Analysis 31: 493-512.

Chung, K. H., and S. W. Pruitt, 1994, A simple approximation of Tobin's q. Financial Management 23 (3): 70-74.

Comment, R., and G. A. Jarrell, 1995, Corporate focus and stock returns. Journal of Financial Economics 37: 67-87.

Cragg, L., and B.Malkiel.1968. The Concensus and Accuracy of Some Predictions of the Growth of Corporate Earnings. Journal of Finance, 23 (9): 67-84. 
Dennis, D. J., D. K. Dennis, and A. Sarin, 1997, Agency problems, equity ownership, and corporate diversification. Journal of Finance 52: 135-160.

Doukas, J.A., C. Kim, and C. Pantzalis, 2000, Security Analysis, Agency Costs and Firm Characteristics. Financial Analysts Journal, :222-222.

Fama, E., Agency Problems and the Theory of the Firm, 1980, Journal of Political Economy, 88: 288-301.

Fama, E. and M. Jensen, 1985, Residual Claims and Investment Decisions. Journal of Financial Economics, 14: 101-119.

Francis, J. and D. Philbrick, 1993, Analysts' Decisions as Products of a Multi-task Environment, Journal of Accounting Research, 31: 216-230.

Elton, E.J., M.J. Gruber, and M. Gultekin.1981. Expectations and Share Prices. Management Science, 27: 975-987.

Gilson, S.C., P. M. Healy, C. F. Noe, and K. G. Palepu, 1998, Information effects of spin-offs, equity carve-outs, and targeted stock offerings, Working paper (Harvard University, Boston, MA).

Givoly, D., and J. Lakonishok. 1984.Earnings Expectation and Properties of Earnings Forecasts-A Review and Analysis of the Research. Journal of Accounting Literature, 3: 85-107.

Harris, M., C.H. Kriebel, and A. Raviv, 1982, Asymmetric information, incentives, and intrafirm resource allocation. Management Science 28: 604-620.

Jensen, M. C., 1986, Agency costs of free cash flow, corporate finance and takeovers. American Economic Review 76: 323-329.

Jensen, M. C., and W. H. Meckling, 1976, Theory of the firm: Managerial behavior, agency costs and ownership structure. Journal of Financial Economics 3: 305-360.

Jensen, M. C., and K. J. Murphy, 1990, Performance pay and top management incentives. Journal of Political Economy 98: 225-264.

Lamont, O., 1997, Cash flow and investment: Evidence from internal capital markets, Journal of Finance 52: 83-109.

Lang, L. H. P., and R. M. Stulz, 1994, Tobin's q, corporate diversification and firm performance. Journal of Political Economy 102: 1248-1280.

La Porta, R. 1996. Expectations and the Cross-Section of Stock Returns. Journal of Finance, 51 (5): 1715-1742. 
Lehn, K., and A. Poulsen, 1989, Free cash flow and stock holder gains in going private transactions, Journal of Finance 44, 771-789.

Lindenberg, E. B. and S.A. Ross, 1981, Tobin's q ratio and industrial organization. Journal of Business 54: 1-32

Logue, D.E., J.K.Seward, and J.P.Walsh, 1996, Rearranging residual claims: A case for targeted stock, Financial Management 25,43-61.

Malkiel, B. 1982. Risk and Return: A New Look, in B.Friedman, ed., The Changing Role of Debt and Equity in Financing U.S. Capital Formation, National Bureau of Economic Research, Chicago, University of Chicago Press.

McConnell, J., and H. Servaes, 1990, Additional evidence on equity ownership and corporate value. Journal of Financial Economics 27: 595-612.

McConnell, J., and H. Servaes, 1995, Equity ownership and the two faces of debt. Journal of Financial Economics 39:131-157.

Merton, R., 1987, A simple model of capital market equilibrium with incomplete information. Journal of Finance 42: 483-510.

Moyer, R. C., R. E. Chatfield, and P. M. Sisneros, 1989, Security analyst monitoring activity: Agency costs and information demands. Journal of Financial and Quantitative Analysis 24: 503-512.

Nanda, V., and M. P. Narayanan, 1997, Disentangling value: Misvaluation and the scope of the firm. University of Michigan Business School. Working paper.

Nohel, T., and V. Tarhan, 1998, Share repurchases and firm performance: New evidence on the agency costs of free cash flow. Journal of Financial Economics 49: 187-222.

Pound, J,1988, Proxy contests and the efficiency of shareholder oversight, Journal of Financial Economics 20: 237-265.

Rajan, R., H. Servaes, and L. Zingales, 2000, The cost of diversity: The diversification discount and inefficient investment, Journal of Finance, 55, 35-80.

Servaes, H., 1996, The value of diversification during the conglomerate merger wave, Journal of Finance, 1201-1225.

Shin, H.H and R.Stulz, 1998, Are internal capital markets efficient? Quarterly Journal of Economics 113, 531-552. 
Shleifer, A. and R. Vishny,1989, Managerial entrenchment: The case of manager-specific investments. Journal of Financial Economics 25: 123-139.

Stulz, R. M., 1990, Managerial discretion and optimal financing policies. Journal of Financial Economics 26: 3-27.

Womack, K., 1996, Do Brokerage analysts' recommendations have investment value? Journal of Finance 51: 137-167. 
Table 1

Summary Statistics for Analyst Coverage, Firm Value, and Selected Control Variables

\begin{tabular}{|c|c|c|c|c|}
\hline Variables & $\begin{array}{l}\text { Net sample } \\
(\mathrm{N}=1027)\end{array}$ & $\begin{array}{c}\text { Smaller firms } \\
30^{\text {th }} \text { percentile } \\
\quad(\mathrm{N}=184)\end{array}$ & $\begin{array}{l}\text { Larger firms } \\
\text { greater than } 30^{\text {th }} \\
\text { Percentile } \\
(\mathbf{N}=\mathbf{8 4 3})\end{array}$ & $\begin{array}{l}\text { [z] }(t)-\text { statistics } \\
\text { for the [median] } \\
\text { (mean) difference } \\
\text { test small-large } \\
\text { firms. }\end{array}$ \\
\hline$Q$ & $\begin{array}{l}2.4709 \\
{[1.570]} \\
(2.3015)\end{array}$ & $\begin{array}{c}4.2620 \\
{[2.8450]} \\
(3.3454)\end{array}$ & $\begin{array}{c}2.0800 \\
{[1.4400]} \\
(1.7799)\end{array}$ & $\begin{array}{l}{[5.11 * * *]} \\
(5.95 * * *)\end{array}$ \\
\hline$L T D$ & $\begin{array}{c}0.1697 \\
{[0.1380]} \\
(0.1661)\end{array}$ & $\begin{array}{c}0.0972 \\
{[0.0380]} \\
(0.1505)\end{array}$ & $\begin{array}{c}0.1854 \\
{[0.1600]} \\
(0.1652)\end{array}$ & $\begin{array}{l}{[-2.17 * *]} \\
(-2.07 * *)\end{array}$ \\
\hline SIZE & $\begin{array}{c}887.00 \\
{[109.00]} \\
(3,268.81)\end{array}$ & $\begin{array}{l}16.9544 \\
{[16.0000]} \\
(10.8267)\end{array}$ & $\begin{array}{c}1,255.49 \\
{[252.00]} \\
(3,841.12)\end{array}$ & $\begin{array}{l}{\left[-19.45^{* * *}\right]} \\
(-58.06 * * *)\end{array}$ \\
\hline$G S$ & $\begin{array}{c}1.1990 \\
{[1.1321]} \\
(0.3558)\end{array}$ & $\begin{array}{c}1.2956 \\
{[1.1849]} \\
(0.5117)\end{array}$ & $\begin{array}{c}1.1810 \\
{[1.1181]} \\
(0.3157)\end{array}$ & $\begin{array}{c}{[1.26]} \\
(1.90 *)\end{array}$ \\
\hline INSIDE & $\begin{array}{c}0.1030 \\
{[0.0240]} \\
(.1544)\end{array}$ & $\begin{array}{c}0.1939 \\
{[0.1500]} \\
(0.1757)\end{array}$ & $\begin{array}{c}0.0807 \\
{[0.0105]} \\
(0.1401)\end{array}$ & $\begin{array}{c}{[3.20 * * *]} \\
(3.07 * *)\end{array}$ \\
\hline INSTIT & $\begin{array}{c}0.2567 \\
{[0.2400]} \\
(0.1671)\end{array}$ & $\begin{array}{c}0.2318 \\
{[0.2200]} \\
(0.1515)\end{array}$ & $\begin{array}{c}0.2628 \\
{[0.2400]} \\
(0.1702)\end{array}$ & $\begin{array}{l}{[-1.60 *]} \\
(-1.92 *)\end{array}$ \\
\hline$N A F$ & $\begin{array}{c}5.9416 \\
{[4.0000]} \\
(5.3928)\end{array}$ & $\begin{array}{c}2.4028 \\
{[2.0000]} \\
(2.1259)\end{array}$ & $\begin{array}{c}7.4391 \\
{[6.0000]} \\
(5.6516)\end{array}$ & $\begin{array}{l}{[-9.65 * * *]} \\
(-9.58 * * *)\end{array}$ \\
\hline$S E G$ & $\begin{array}{c}2.7768 \\
{[2.0000]} \\
(1.9518)\end{array}$ & $\begin{array}{c}2.1022 \\
{[2.0000]} \\
(1.6511)\end{array}$ & $\begin{array}{c}2.9430 \\
{[3.0000]} \\
(1.9849)\end{array}$ & $\begin{array}{l}{[-2.95 * *]} \\
\left(-2.40^{* *}\right)\end{array}$ \\
\hline
\end{tabular}

Note: Descriptive statistics for selected financial and ownership structure variables for the sample of firms over the period 1998-2001, and for those firms below the smaller 30th percentile as well as those firms with reside above the 30th percentile. Reported are the means [medians] and standard deviations (in parentheses) 
Table 2

Regression Results for Agency Costs and Analyst Coverage Panel A: Q-Based Agency Cost

\begin{tabular}{|c|c|c|}
\hline \multirow[b]{2}{*}{ Variables } & \multicolumn{2}{|c|}{ Dependent Variable: Q-bases Agency Cost } \\
\hline & $\begin{array}{c}\text { One year ahead } \\
\text { forecasting horizon }\end{array}$ & $\begin{array}{l}\text { Two years ahead } \\
\text { forecasting horizon }\end{array}$ \\
\hline Intercept & $\begin{array}{l}0.008 \\
(0.545)\end{array}$ & $\begin{array}{c}0.003 \\
(0.840)\end{array}$ \\
\hline$N A F$ & $\begin{array}{c}0.006 \\
(0.816)\end{array}$ & $\begin{array}{c}0.003 \\
(0.906)\end{array}$ \\
\hline$N A F \times D U M-S$ & $\begin{array}{c}-0.016 * * * \\
(-3.260)\end{array}$ & $\begin{array}{c}-0.012 * * * \\
(-2.328)\end{array}$ \\
\hline$N A F \times D U M-L$ & $\begin{array}{c}-0.001 \\
(-0.833)\end{array}$ & $\begin{array}{c}-0.003 \\
(-0.660)\end{array}$ \\
\hline INSIDE & $\begin{array}{c}0.003 \\
(0.766)\end{array}$ & $\begin{array}{c}0.003 \\
(0.858)\end{array}$ \\
\hline$I N S I D E^{2}$ & $\begin{array}{c}0.002 \\
(0.974)\end{array}$ & $\begin{array}{c}0.006 \\
(0.868)\end{array}$ \\
\hline INSTIT & $\begin{array}{c}0.003 \\
(0.414)\end{array}$ & $\begin{array}{c}0.004 \\
(0.552)\end{array}$ \\
\hline$L T D$ & $\begin{array}{c}-0.011 \\
(-0.388)\end{array}$ & $\begin{array}{c}-0.013 \\
(-0.270)\end{array}$ \\
\hline$L T D^{2}$ & $\begin{array}{c}-0.003 \\
(-0.856)\end{array}$ & $\begin{array}{c}-0.001 \\
(-0.978)\end{array}$ \\
\hline SIZE & $\begin{array}{l}0.001 \\
(0.890)\end{array}$ & $\begin{array}{c}0.001 \\
(0.526)\end{array}$ \\
\hline $\mathrm{N}$ & 769 & 766 \\
\hline $\operatorname{Adj}-R^{2}$ & 0.013 & 0.006 \\
\hline
\end{tabular}

Note: AGENCY [ = Qdummy x FCF] is the interaction of a growth opportunities indicator and firm's free cash flow standardized by size. Poor growth opportunities are measured by a dummy variable that takes the value of one if the firm's Tobin's q is less than the median (and the value of zero otherwise). Free cash flow is measured as [(Operating Income before Depreciation) - (Taxes + Interest Expense + Dividends paid)]/(Total Assets). *, **, *** denote significance at the $10 \%, 5 \%$, and $1 \%$ level, respectively. 
Panel B: Median Growth of Sales-Based Agency Cost

\begin{tabular}{|c|c|c|c|}
\hline & \multicolumn{3}{|c|}{ Dependent Variable: Median Growth in Sales-Based Agency Cost } \\
\hline & Variables & $\begin{array}{c}\text { One year ahead } \\
\text { forecasting horizon }\end{array}$ & $\begin{array}{c}\text { Two years ahead } \\
\text { forecasting horizon }\end{array}$ \\
\hline & Intercept & $\begin{array}{c}-0.151 * * * \\
(-4.283)\end{array}$ & $\begin{array}{c}-0.126 * * * \\
(-3.774)\end{array}$ \\
\hline & $N A F$ & $\begin{array}{c}0.010 \\
(0.114)\end{array}$ & $\begin{array}{c}0.017 \\
(0.078)\end{array}$ \\
\hline & $N A F \times D U M-S$ & $\begin{array}{c}-0.047 * * * \\
(-4.166)\end{array}$ & $\begin{array}{l}-0.032 * * \\
(-2.919)\end{array}$ \\
\hline & $N A F \times D U M-L$ & $\begin{array}{c}0.012 \\
(0.217)\end{array}$ & $\begin{array}{c}0.006 \\
(0.499)\end{array}$ \\
\hline & INSIDE & $\begin{array}{c}0.030 \\
(0.579)\end{array}$ & $\begin{array}{c}0.019 \\
(0.700)\end{array}$ \\
\hline & $I N S I D E^{2}$ & $\begin{array}{c}0.028 \\
(0.775)\end{array}$ & $\begin{array}{c}0.032 \\
(0.732)\end{array}$ \\
\hline & INSTIT & $\begin{array}{c}0.055 \\
(0.002)\end{array}$ & $\begin{array}{c}0.045 \\
(0.007)\end{array}$ \\
\hline & $L T D$ & $\begin{array}{l}.0001 \\
(0.001)\end{array}$ & $\begin{array}{c}-0.002 \\
(-0.224)\end{array}$ \\
\hline & $L T D^{2}$ & $\begin{array}{c}0.031 \\
(0.644)\end{array}$ & $\begin{array}{c}0.033 \\
(0.735)\end{array}$ \\
\hline & SIZE & $\begin{array}{c}0.008 * * * \\
(4.773)\end{array}$ & $\begin{array}{c}0.007 * * * \\
(4.402)\end{array}$ \\
\hline & $\mathrm{N}$ & 842 & 840 \\
\hline & Adj-R $R^{2}$ & 0.071 & 0.044 \\
\hline Note: & $\begin{array}{l}\text { AGENCY [= GS-DUMMY x FC } \\
\text { cash flow standardized by size. P } \\
\text { the value of one if the firm's five } \\
\text { of zero otherwise). Free cash flo } \\
\text { Interest Expense + Dividends pai }\end{array}$ & $\begin{array}{l}\text { is the interaction of a grow } \\
\text { growth opportunities are } \\
\text { ar growth of sales [GS] is } \\
\text { s measured as [(Operating } \\
\text { /(Total Assets). }\end{array}$ & $\begin{array}{l}\text { opportunities indicator and firm's free } \\
\text { easured by a dummy variable that takes } \\
\text { ss than the sample median (and the value } \\
\text { come before Depreciation) - (Taxes + }\end{array}$ \\
\hline
\end{tabular}




\section{Panel C: Median of Operating Expense-Based Agency Cost}

\begin{tabular}{|c|c|c|}
\hline \multicolumn{3}{|c|}{ Dependent Variable: Median of Operating Expense-Based Agency Cost } \\
\hline Variables & $\begin{array}{l}\text { One year ahead } \\
\text { forecasting horizon }\end{array}$ & $\begin{array}{l}\text { Two years ahead } \\
\text { forecasting horizon }\end{array}$ \\
\hline Intercept & $\begin{array}{c}-0.319 * * * \\
(-8.036)\end{array}$ & $\begin{array}{c}-0.305 * * * \\
(-8.217)\end{array}$ \\
\hline$N A F$ & $\begin{array}{l}0.003 \\
(1.059)\end{array}$ & $\begin{array}{c}0.003 \\
(0.997)\end{array}$ \\
\hline$N A F \times D U M-S$ & $\begin{array}{c}-0.086 * * * \\
(-6.823)\end{array}$ & $\begin{array}{c}-0.079 * * * \\
(-6.438)\end{array}$ \\
\hline$N A F \times D U M-L$ & $\begin{array}{l}-0.003 \\
(-0.274)\end{array}$ & $\begin{array}{l}-0.006 \\
(-0.613)\end{array}$ \\
\hline INSIDE & $\begin{array}{l}0.109 * \\
(1.794)\end{array}$ & $\begin{array}{l}0.135 * * \\
(2.353)\end{array}$ \\
\hline$I N S I D E^{2}$ & $\begin{array}{c}0.020 \\
(-0.180)\end{array}$ & $\begin{array}{l}-0.071 \\
(-0.687)\end{array}$ \\
\hline INSTIT & $\begin{array}{c}0.080 * * * \\
(4.064)\end{array}$ & $\begin{array}{c}0.064 * * * \\
(3.447)\end{array}$ \\
\hline$L T D$ & $\begin{array}{c}-0.037 \\
(-0.931)\end{array}$ & $\begin{array}{c}-0.048 \\
(-1.338)\end{array}$ \\
\hline$L T D^{2}$ & $\begin{array}{c}0.020 \\
(0.813)\end{array}$ & $\begin{array}{c}0.048 \\
(0.971)\end{array}$ \\
\hline SIZE & $\begin{array}{c}0.015 * * * \\
(8.298)\end{array}$ & $\begin{array}{c}0.015 * * * \\
(8.641)\end{array}$ \\
\hline $\mathrm{N}$ & 842 & 840 \\
\hline $\operatorname{Adj}-R^{2}$ & 0.167 & 0.155 \\
\hline
\end{tabular}

Note: AGENCY [ = OE-Dummy x FCF] is the interaction of a growth opportunities indicator and firm's free cash flow standardised by total assets. Agency cost is measured by a dummy variable that takes the value of one if the firm's operating expense ratio is greater than the sample median (and the value of zero otherwise). Operating expense ratio is defined as total expenses less cost of good sold, interest expense, and depreciation standardised by total annual sales. Excessive expense on nonessentials including perks should be reflected in this agency cost variable. Free cash flow is measured as [(Operating Income before Depreciation) - (Taxes + Interest Expense + Dividends paid)]/(Total Assets). 
Table 3

Regression Results for Firm Value and Analyst Coverage

Panel A: Q-Based Value

\begin{tabular}{|c|c|c|}
\hline \multirow[b]{2}{*}{ Variables } & \multicolumn{2}{|c|}{ Dependent Variable: Q-based Value } \\
\hline & $\begin{array}{l}\text { One year ahead } \\
\text { forecasting horizon }\end{array}$ & $\begin{array}{l}\text { Two years ahead } \\
\text { forecasting horizon }\end{array}$ \\
\hline Intercept & $\begin{array}{l}9.823 * * * \\
(11.338)\end{array}$ & $\begin{array}{c}10.130 * * * \\
(11.796)\end{array}$ \\
\hline$N A F$ & $\begin{array}{l}0.308^{*} \\
(1.866)\end{array}$ & $\begin{array}{c}0.318^{* *} \\
(1.996)\end{array}$ \\
\hline$N A F \times D U M-S$ & $\begin{array}{l}0.625 * * \\
(2.459)\end{array}$ & $\begin{array}{l}0.542 * * \\
(2.113)\end{array}$ \\
\hline$N A F \times D U M-L$ & $\begin{array}{c}0.185 \\
(0.728)\end{array}$ & $\begin{array}{c}0.106 \\
(0.430)\end{array}$ \\
\hline INSIDE & $\begin{array}{c}0.991 \\
(0.721)\end{array}$ & $\begin{array}{l}1.020 \\
(0.774)\end{array}$ \\
\hline$I N S I D E^{2}$ & $\begin{array}{c}-0.428 \\
(-0.170)\end{array}$ & $\begin{array}{c}-0.479 \\
(-0.192)\end{array}$ \\
\hline INSTIT & $\begin{array}{c}-1.590 * * * \\
(-3.667)\end{array}$ & $\begin{array}{c}-1.718 * * * \\
(-3.952)\end{array}$ \\
\hline$L T D$ & $\begin{array}{c}-5.592 * * * \\
(-6.966)\end{array}$ & $\begin{array}{l}-5.429 * * * \\
(-6.805)\end{array}$ \\
\hline$L T D^{2}$ & $\begin{array}{c}7.795^{* * * *} \\
(7.760)\end{array}$ & $\begin{array}{c}7.690 * * * \\
(7.673)\end{array}$ \\
\hline SIZE & $\begin{array}{c}-0343 * * * \\
(-8.307)\end{array}$ & $\begin{array}{c}-0.357 * * * \\
(-8.725)\end{array}$ \\
\hline $\mathrm{N}$ & 962 & 959 \\
\hline Adj- $R^{2}$ & 0.229 & 0.229 \\
\hline
\end{tabular}

Note: Q is estimated corresponding to that suggested by McConnel and Servaes (1990), denoted as market value of equitybook value of debt standardised by total assets. 
Panel B: EMV-Based Value

\begin{tabular}{|c|c|c|}
\hline \multirow[b]{2}{*}{ Variables } & \multicolumn{2}{|c|}{ Dependent Variable: EMV-Based Value } \\
\hline & $\begin{array}{c}\text { One year ahead } \\
\text { forecasting horizon }\end{array}$ & $\begin{array}{c}\text { Two years ahead } \\
\text { forecasting horizon }\end{array}$ \\
\hline Intercept & $\begin{array}{l}30.001 * * * \\
(7.883)\end{array}$ & $\begin{array}{l}30.924 * * * \\
(9.325)\end{array}$ \\
\hline$N A F$ & $\begin{array}{l}1.907 * * * \\
(5.457)\end{array}$ & $\begin{array}{l}1.594 * * * \\
(4.631)\end{array}$ \\
\hline$N A F \times D U M-S$ & $\begin{array}{l}3.762 * * * \\
(6.937)\end{array}$ & $\begin{array}{l}3.837 * * * \\
(6.883)\end{array}$ \\
\hline$N A F \times D U M-L$ & $\begin{array}{c}-.815 \\
(-1.508)\end{array}$ & $\begin{array}{l}-0.590 \\
(-1.107)\end{array}$ \\
\hline INSIDE & $\begin{array}{c}-9.492 * * \\
(-3.237)\end{array}$ & $\begin{array}{l}-9.360 * * \\
(-3.145)\end{array}$ \\
\hline$I N S I D E^{2}$ & $\begin{array}{l}13.654 * * \\
(2.548)\end{array}$ & $\begin{array}{l}12.779 * * \\
(2.359)\end{array}$ \\
\hline INSTIT & $\begin{array}{l}-5.775 * * * \\
(-6.234)\end{array}$ & $\begin{array}{l}-6.030 * * \\
(-6.370)\end{array}$ \\
\hline$L T D$ & $\begin{array}{l}-1.644 \\
(-0.961)\end{array}$ & $\begin{array}{l}-1.073 \\
(-0.620)\end{array}$ \\
\hline$L T D^{2}$ & $\begin{array}{l}5.044 * * \\
(2.349)\end{array}$ & $\begin{array}{l}4.491 * * \\
(2.060)\end{array}$ \\
\hline$S I Z E$ & $\begin{array}{c}-1.280 * * * \\
(-14.439)\end{array}$ & $\begin{array}{c}-1.324 * * * \\
(-14.721)\end{array}$ \\
\hline $\mathrm{N}$ & 973 & 968 \\
\hline Adj-R ${ }^{2}$ & 0.409 & 0.385 \\
\hline
\end{tabular}

Note: EMV is the defined as the market value of equity - book value of equity standardised by total annual sales. 
Figure 1

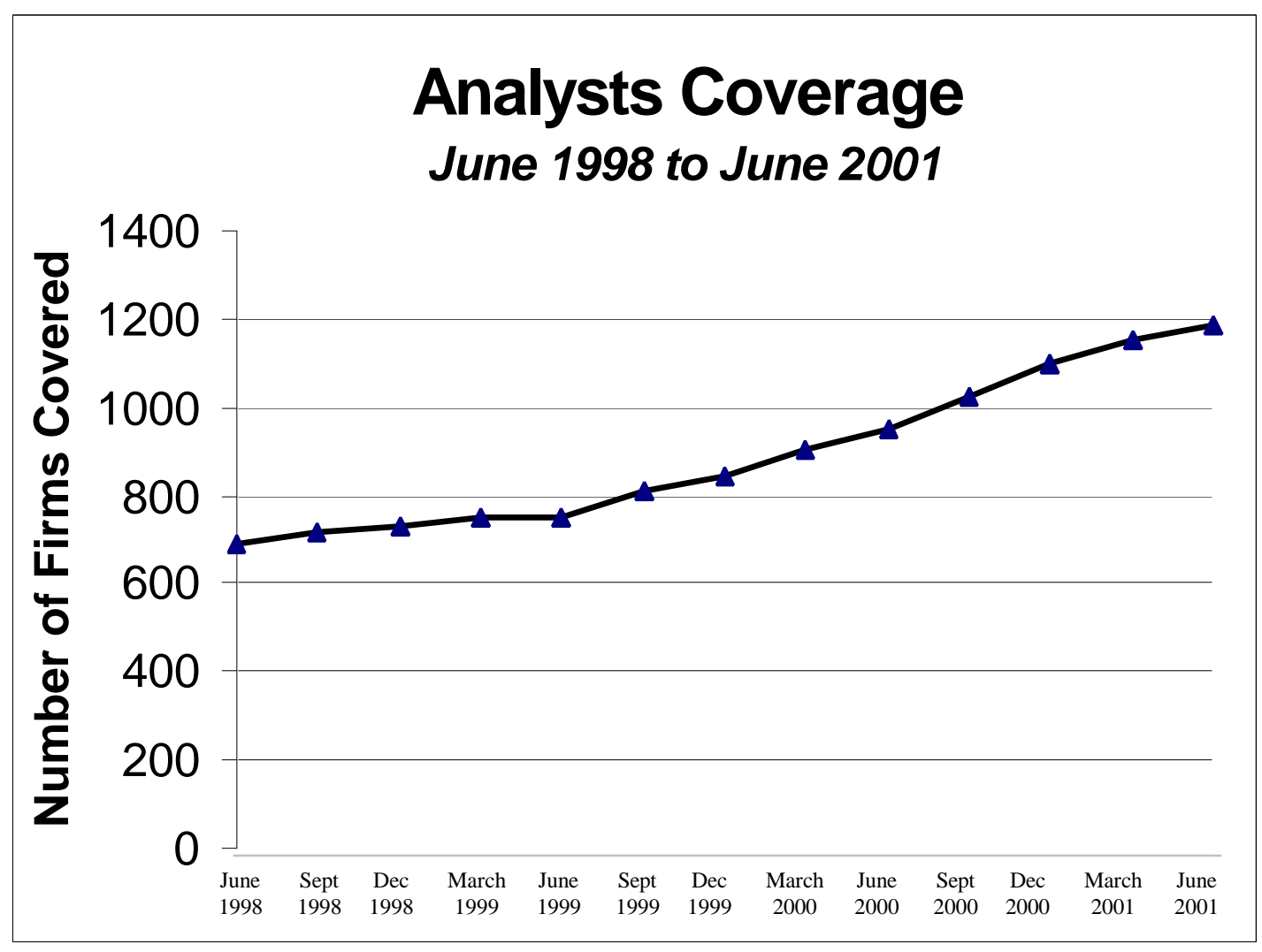

